\title{
Kajian Perbandingan Analisa Usaha Tani serta Produktivitas Tanaman Cabai Rawit di Dalam Polibag dan di Lahan Pekarangan
}

\author{
Siti M. Sholihah ${ }^{(1)}$, Luluk Syahr Banu ${ }^{(1)}$, Ani Nuraini ${ }^{(2)}$, Petrus Amrih Piguno ${ }^{(2)}$ \\ ${ }^{(1)}$ Prodi Agroteknologi Fakultas Pertanian Universitas Respati Indonesia Jakarta \\ ${ }^{(2)}$ Prodi Manajemen Fakultas Manajemen Bisnis Universitas Respati Indonesia Jakarta \\ Email: nur.sholihah18@gmail.com
}

\begin{abstract}
ABSTRAK
Cabai merupakan salah satu komoditas hortikultura yang dibudidayakan secara komersial di negara-negara tropis termasuk Indonesia. Budidaya tanaman cabai rawit mempunyai prospek cerah karena dapat mendukung upaya peningkatan pendapatan petani, pengentasan kemiskinan, perluasan kesempatan kerja, pengurangan impor, dan peningkatan ekspor non migas. Kebutuhan terhadap cabai terus meningkat setiap tahun sejalan dengan meningkatnya jumlah penduduk dan perekonomian nasional. Penelitian ini dilaksanakan di kebun percobaan Fakultas Pertanian Universitas Respati Indonesia Jakarta pada bulan Juli sampai bulan Desember 2019. Metode penelitian ini merupakan penelitian eksperimen semu dengan pendekatan kuantitatif. Perlakuan terdiri atas penanaman cabai rawit di lahan dan di dalam polibag, jumlah tanaman per pelakuan adalah 20 tanaman, sehingga jumlah tanaman seluruhnya 40 tanaman. Variabel penelitian meliputi tinggi tanaman, jumlah daun, jumlah buah, berat segar, produktivitas, analisa usaha. Hasil penelitian menunjukkan bahwa produktivitas cabai rawit yang ditanam di lahan pekarangan lebih besar $(3,141$ ton/ha) dari pada di polibag (1,927 ton/ha). Berdasarkan analisis usaha tani, tingkat efisiensi ekonomi budidaya cabai rawit masih rendah, nilai RC-ratio $<1$, sehingga tidak efisien dan tidak dilayak dilakukan dan perlu dikaji ulang.
\end{abstract}

Kata kunci : cabai rawit, pertumbuhan, produktivitas, analisa usaha

\begin{abstract}
Chili is one of the horticultural commodities that are commercially cultivated in tropical countries including Indonesia. The cultivation of cayenne pepper has a bright prospect because it can support efforts to increase farmers' incomes, reduce poverty, expand employment opportunities, reduce imports, and increase non-oil exports. The need for chili continues to increase every year in line with the increasing population and national economy. This research was conducted in the experimental garden of the Faculty of Agriculture, University of Respati Indonesia Jakarta in July to December 2019. This research method is a quasi-experimental study with a quantitative approach. The treatment consists of planting cayenne pepper in the field and inside the polybag, the number of plants per treatment is 20 plants, so that the total number of plants is 40 plants. Research variables include plant height, number of leaves, number of fruits, fresh weight, productivity, business analysis. The results showed that the productivity of cayenne pepper planted in the plot was greater $(3,141$ tons / ha) than in polybags (1,927 tons / ha). Based on the analysis of farming,
\end{abstract}

http://ejournal.urindo.ac.id/index.php/pertanian

Article History :

Sumbitted 08 Juni 2020, Accepted 29 Juni 2020, Published 30 Juni 2020 


\section{Jurnal IImiah Respati}

the level of economic efficiency of cayenne pepper cultivation is still low, the RC-ratio value $<1$, so it is inefficient and not worth doing and needs to be reviewed.

Keywords: cayenne pepper, growth, productivity, business analysis

\section{PENDAHULUAN}

Cabai merupakan salah satu komoditas pertanian yang penting dan banyak dibudidayakan di Indonesia. Cabai memiliki aroma, rasa dan warna yang spesifik, sehingga banyak digunakan oleh masyarakat sebagai rempah dan bumbu masakan. Seiring dengan bertambahnya penduduk, kebutuhan cabai di Indonesia pun semakin meningkat [1].

Produksi cabai rawit di Indonesia dalam lima tahun terakhir (2010 - 2014), menunjukkan peningkatan dengan pertumbuhan sekitar 8,36 \% (BPS, 2015). Peningkatan produksi cabai rawit berdasarkan data pada tahun 2010 2014 tetap tidak dapat memenuhi kebutuhan cabai rawit nasional, sehingga impor cabai rawit terus dilakukan setiap tahunnya, hal ini dikarenakan belum tercapainya potensi terhadap produksi cabai rawit sebesar $10-20$ ton/ha [2].

Pemenuhan kebutuhan

konsumsi cabai rawit nasional yang semakin meningkat dapat ditunjang oleh peningkatan produksi cabai rawit. Kemampuan produksi cabai rawit

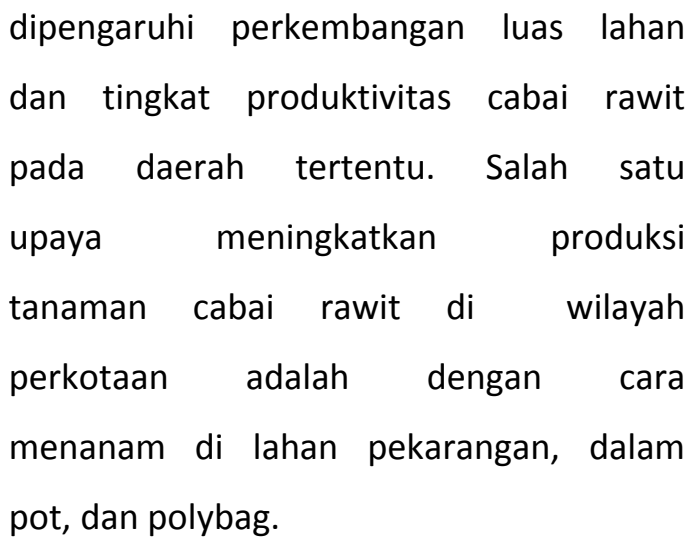

Tanaman cabai merupakan salah satu sayuran buah yang memiliki peluang bisnis yang baik. Besarnya kebutuhan dalam negeri maupun luar negeri menjadikan cabai sebagai komoditas menjanjikan. Permintaan cabai yang tinggi untuk kebutuhan bumbu masakan, industri makanan, dan obat - obatan merupakan potensi untuk meraup keuntungan. Tidak heran jika cabai merupakan komoditas hortikultura yang mengalami fluktuasi harga paling tinggi di Indonesia. Harga cabai yang tinggi memberikan keuntungan yang tinggi pula bagi petani. Keuntungan yang diperoleh dari budidaya cabai umumnya lebih tinggi dibandingkan dengan budidaya sayuran lain. Tanaman Cabai pun kini menjadi komoditas ekspor yang menjanjikan. Namun, banyak kendala yang dihadapi petani dalam berbudidaya cabai. Salah satunya 
adalah hama dan penyakit seperti kutu kebul, antraknosa, dan busuk buah yang menyebabkan gagal panen [3].

Selain itu, produktivitas buah yang rendah dan waktu panen yang lama tentunya akan memperkecil rasio keuntungan petani cabai. Hasil penelitian [4], budidaya cabai rawit varietas rama menggunakan pupuk NPK $400 \mathrm{~kg} / \mathrm{ha}$ dalam polybag memberikan keuntungan $\mathrm{Rp}$. 147.781.600/musim/ha atau Rp 24.630.266/ bulan/ha. Nilai RC-ratio > $1(6,135)$ yang berarti usaha tani cabai rawit efisien dan mampu berdaya saing. Analisa usaha tani tanaman cabai merah (Capsicum annum L) menggunakan media tanam limbah kelapa sawit dalam polybag memberikan keuntungan 3.761.500, nilai RC-ratio 2,19, dapat memenuhi pangan keluarga dan layak dikembangkan sebagai sumber pendapatan keluarga (Qomariah dan Pramudyani, 2015). Sedangkan usaha tani cabai di lahan oleh petani di desa Antapan, menurut hasil penelitian [5], petani memperoleh keuntungan sebesar Rp. 86.186.000 dan nilai RCratio sebesar 20,4 .

Pada umumnya budidaya cabai rawit oleh petani, ibu-ibu rumah tangga di wilayah perkotaan menggunakan pupuk kandang sapi, disebabkan mudah diperoleh, harga murah dan banyak dijual di toko-toko pertanian. Berdasarkan uraian di atas, maka perlu dilakukan penelitian tentang kajian pertumbuhan dan produktivitas serta analisa usaha tani cabai rawit menggunakan pupuk kandang sapi di lahan pekarangan dan di dalam polibag.

\section{METODE}

\section{Bahan dan Alat}

Bahan untuk kegiatan penelitian ini adalah benih cabai rawit, media tanam siap pakai, pupuk kandang sapi, sekam, pupuk NPK, polibag ukurun $40 \times 40 \mathrm{~cm}$. Pestisida yang digunakan untuk pengendalian serangan hama dan penyakit pada tanaman cabai rawit digunakan pestisida kimia Curacron.

Alat yang digunakan untuk kegiatan penelitian ini adalah, bambu/ajir, selang, timbangan duduk, baki/tray, nampan, tali rafia, cangkul, sabit, label, ember, alat tulis, handsprayer, penggaris, dan polibag ukuran $40 \times 40 \mathrm{~cm}$.

\section{Rancangan Penelitian}

Metode penelitian ini merupakan penelitian eksperimen semu dengan pendekatan kuantitatif. Perlakuan terdiri atas penanaman cabai rawit di lahan pekarangan dan di dalam polibag. Jumlah tanaman per pelakuan adalah 20 tanaman, 
sehingga jumlah tanaman seluruhnya 40 tanaman.

\section{Variabel Penelitian}

a. Tinggi tanaman $(\mathrm{cm})$

Tinggi tanaman diperoleh dengan mengukur tanaman dari pangkal batang hingga pucuk daun tertinggi. Pengamatan dilakukan pada umur 14HST, 28 HST, dan 42 HST.

b. Jumlah Daun (helai) Menghitung jumlah semua daun, pada pada umur $14 \mathrm{HST}$, $28 \mathrm{HST}$, dan $42 \mathrm{HST}$ saat panen.

c. Berat segar buah per tanaman (gram)

Menimbang langsung berat segar buah cabai rawit pada saat panen.

\section{Analisa Data}

1. Data kuantitatif yang diperoleh ditabulasi menggunakan Microsoft Excel dan perbedaan tempat penanaman terhadap variabel terikat dianalisis menggunakan Uji Independent T-test.

2. Analisis Usaha Tani : untuk mengukur prinsip-prinsip ekonomi dalam usaha tani, meliputi : biaya, penerimaan, keuntungan, dan RC-ratio.

a. Biaya

Biaya total dari usaha tani cabai rawit varietas Lentera F1 dihitung dengan menggunakan rumus sebagai berikut

$\mathrm{TC}=\mathrm{TFC}+\mathrm{TVC}$

Keterangan :
$\mathrm{TC}=$ Biaya total dari usaha tani cabai rawit kresna (Rp)

TFC = Total biaya tetap dari usaha tani cabai rawit kresna (Rp)

TVC $=$ Total biaya variabel dari usaha tani cabai rawit kresna $(\mathrm{Rp})$

b. Penerimaan

Nilai penerimaan total biaya total dari usaha tani cabai rawit varietas kresna dihitung dengan menggunakan rumus sebagai berikut

$T R=T P P \times p$

Keterangan :

$\mathrm{TR}$ = Penerimaan total dari usaha tani cabai rawit kresna ( $R p)$

TPP = Total phisical produk dari usaha tani cabai rawit kresna $(\mathrm{Rp})$

$\mathrm{P} \quad=$ Harga produk per unit dari usaha tani cabai rawit kresna $(\mathrm{Rp} / \mathrm{kg})$

c.. Keuntungan Usaha Tani, dihitung dengan menggunakan rumus sebagai berikiut :

$\pi=\mathrm{TR}-\mathrm{TC}$

Keterangan :

$\pi=$ Keuntungan usaha tani cabai rawit kresna $(\mathrm{Rp})$

$\mathrm{TR}=$ Penerimaan total dari usaha tani cabai rawit kresna (Rp)

TC = Biaya total dari usaha tani cabai rawit kresna (Rp) 
d. RC-Ratio : analisis imbangan biaya dan penerimaan

$$
\begin{aligned}
& \text { Analisis ini dapat dipakai untuk } \\
& \text { mengetahui tingkat efiesiensi } \\
& \text { ekonomi dan menunjukkan daya } \\
& \text { saing dari produk yang dihasilkan } \\
& \text { pada usaha tani. } \\
& \text { Secara mateamatika dapat } \\
& \text { diformulasikan sebagai berikut : } \\
& \text { RC-Ratio = } \underline{\text { TR }} \\
& \text { Keterangan : } \\
& \text { RC-Ratio = Return and cost Ratio } \\
& \text { TR = Total Revenue }
\end{aligned}
$$

TC $=$ Total cost

\section{HASIL DAN PEMBAHASAN}

\section{Pengamatan Tanaman Cabai Rawit}

Tinggi Tanaman $(\mathrm{cm})$

Tinggi tanaman Cabai Rawit diukur pada saat umur $14 \mathrm{HST}$, dan dilakukan 3 kali pengukuran, yaitu 14 HST, 28 HST, dan 42 HST. Berdasarkan uji independet T- test, tinggi tanaman cabai rawit yang ditanam di lahan lebih besar dari pada di polibag. Hasil pengamatan tinggi tanaman dapat dilihat pada Tabel 1.

Tabel 1. Tinggi Tanaman (cm) Cabai Rawit di Lahan dan di Polibag

\begin{tabular}{lrrr}
\hline Perlakuan & \multicolumn{3}{c}{ Tinggi Tanaman (cm) } \\
\cline { 2 - 4 } & 14 HST & 28 HST & 42 HST \\
\hline T (lahan) & 7.725 & 21.645 & 42.955 \\
P (polibag) & 8.635 & 16.785 & 37.230 \\
\hline Signifikasi & 1.471 & $3.424^{*}$ & $2.191^{*}$ \\
\hline
\end{tabular}

Keterangan : * = signifikan pada taraf kepercayaan $95 \%$

Budidaya cabai rawit yang di lahan, dalam menyerap air dan unsur hara di membuat perakaran lebih mudah dalam tanah. Tanah yang dicampur berkembang, dan daya topang tanah dengan pupuk organik (pupuk kandang terhadap tanaman lebih kuat, ditambah dengan adanya pupuk organik dan sapi) akan memberi ruang pori lebih baik, mikroorganisme di dalam tanah. Dengan demikian sifat fisik dan biologi tanah menjadi lebih baik, maka pertumbuhan tinggi tanaman menjadi lebih optimal. Sifat fisik media yang baik menyebabkan sistem perakaran tanaman berfungsi dengan baik mikroorganisme tanah mudah berkembang dan aktif, serta kelembaban media terjaga [6].

\section{Jumlah Daun (helai)}

Jumlah daun tanaman Cabai Rawit diukur pada saat umur 14 HST, dan dilakukan 3 kali pengukuran, yaitu 14 


\section{Jurnal IImiah Respati}

HST, 28 HST, dan 42 HST. Berdasarkan

uji independet $T$ - test, jumlah daun

tanaman cabai rawit yang ditanam di

lahan lebih besar dari pada di polibag.

Tabel 2. Jumlah Daun (helai) Cabai Rawit di Lahan dan di Polibag

\begin{tabular}{lcrc}
\hline Perlakuan & \multicolumn{3}{c}{ Jumlah daun (helai) } \\
\cline { 2 - 4 } & 14 HST & 28 HST & 42 HST \\
\hline & & & \\
T (lahan) & 9.850 & 20.600 & 130.950 \\
P (polibag) & 7.500 & 16.000 & 100.950 \\
& & & \\
\hline Signifikasi & $4.459 *$ & $3.695 *$ & $2.201 *$
\end{tabular}

Hasil pengamatan jumlah daun dapat dilihat pada Tabel 2.

Keterangan : * signifikan pada taraf kepercayaan 95\%

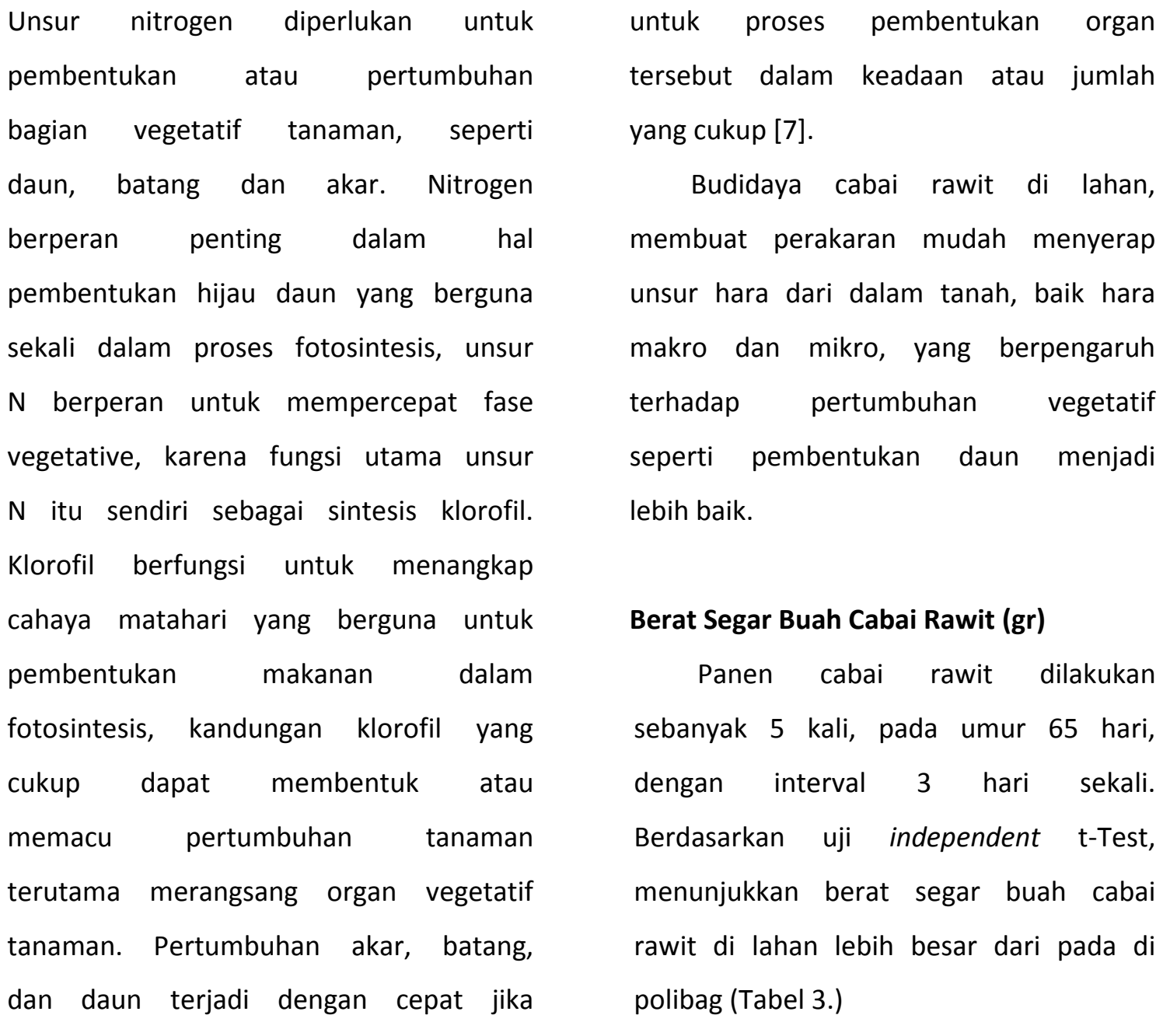


Tabel 3. Berat Segar Buah Cabai Rawit (gr) di Lahan dan di Polibag

\begin{tabular}{|c|c|c|}
\hline \multirow[t]{2}{*}{ Perlakuan } & Berat Segar buah (gr) & \multirow[t]{2}{*}{ Signifikasi } \\
\hline & 77 HST & \\
\hline $\mathrm{T}$ (lahan) & 1885 & $5.715 *$ \\
\hline P (polibag) & 1557 & \\
\hline
\end{tabular}

Keterangan : ${ }^{*}=$ signifikan pada taraf kepercayaan $95 \%$

Suatu tanaman akan tumbuh subur apabila unsur hara yang dibutuhkan cukup tersedia dalam bentuk yang sesuai untuk diserap tanaman. Ketersediaan unsur hara seperti N, P dan $\mathrm{K}$ dalam tanah menentukan hasil tanaman. Tercukupinya unsur fosfor dan kalium, akan menyebabkan aktivitas enzim meningkat sehingga proses metabolisme di dalam tanaman meningkat. Unsur hara $P$ mempunyai peranan penting dalam memacu perkembangan buah. Fosfor merupakan bagian yang essensial dalam reaksi-reaksi pada proses fotosintesis. Pada masa generatif, ketersediaan dan translokasi hasil fotosintesis yang baik akan dapat menghasilkan jumlah buah lebih banyak [8]. Pertumbuhan vegetatif yang baik dapat pula memberikan kontribusi yang positif terhadap pertumbuhan [9].

\section{Produktivitas Tanaman Cabai Rawit} (ton/ha)

Produktivitas tanaman cabai rawit, berdasarkan uji independent Ttest, menunjukkan produktivitas cabai rawit yang di tanam di lahan lebih besar dari pada di polibag (Tabel 4.).

Tabel 4. Produktivitas Cabai Rawit (kg/ha) di Lahan dan di Polibag

\begin{tabular}{lcl}
\hline Perlakuan & Produktivitas (ton/ha) & Signifikasi \\
\hline & & \\
\hline P (lahan) & 3,141 & $5.715^{*}$ \\
(polibag) & 1,927 & \\
\hline
\end{tabular}

Keterangan : ${ }^{*}=$ signifikan pada taraf kepercayaan $95 \%$

Produktivitas berhubungan dengan tanaman. Semakin besar hasil panen hasil panen cabai rawit dengan luas maka produktivitas meningkat. lahan yang digunakan pada budidaya Produktivitas cabai rawit di lahan 
Jurnal IImiah Respati

sebesar 3,141 ton/ha, sedangkan di

Biaya total dari usaha tani cabai rawit polibag sebesar 1,927 ton/ha.

varietas Lentera F1 merupakan

ANALISIS USAHA TANI

penjumlahan biaya tetap dan biaya

Biaya

variabel (Tabel 4.)

Tabel 5. Biaya Total Usaha Tani Cabai Rawit di Lahan dan di Polibag

\begin{tabular}{|c|c|c|c|}
\hline Perlakuan & $\begin{array}{l}\text { Biaya Tetap } \\
\text { (Rp) }\end{array}$ & $\begin{array}{l}\text { Biaya Variabel } \\
\text { (Rp) }\end{array}$ & $\begin{array}{l}\text { Biaya Total } \\
\text { (Rp) }\end{array}$ \\
\hline T (lahan) & 180.000 & 456.250 & 636.250 \\
\hline P (polibag) & 60.000 & 416.250 & 476.250 \\
\hline
\end{tabular}

Berdasarkan Tabel 4., biaya lahan lebih banyak kegiatan yang total usaha tani cabai rawit di lahan dilakukan antara lain : pengolahan lebih besar (Rp. 636.250) dari pada di tanah, perawatan, penyiraman, dan polibag (Rp. 476.250). Hal ini pemanenan dibandingkan di polibag.

disebabkan bertanam cabi rawit di

\section{Penerimaan}

Tabel 6. Penerimaan Usaha Tani Cabai Rawit di Lahan dan di Polibag

\begin{tabular}{lccc}
\hline Perlakuan & $\begin{array}{c}\text { Hasil Cabai Rawit } \\
(\mathrm{kg})\end{array}$ & Harga per kg & $\begin{array}{c}\text { Jumlah Penerimaan } \\
(\mathrm{Rp})\end{array}$ \\
\hline T (lahan) & 1,885 & 50.000 & 94.250 \\
P (polibag) & 1,157 & 50.000 & 57.850
\end{tabular}

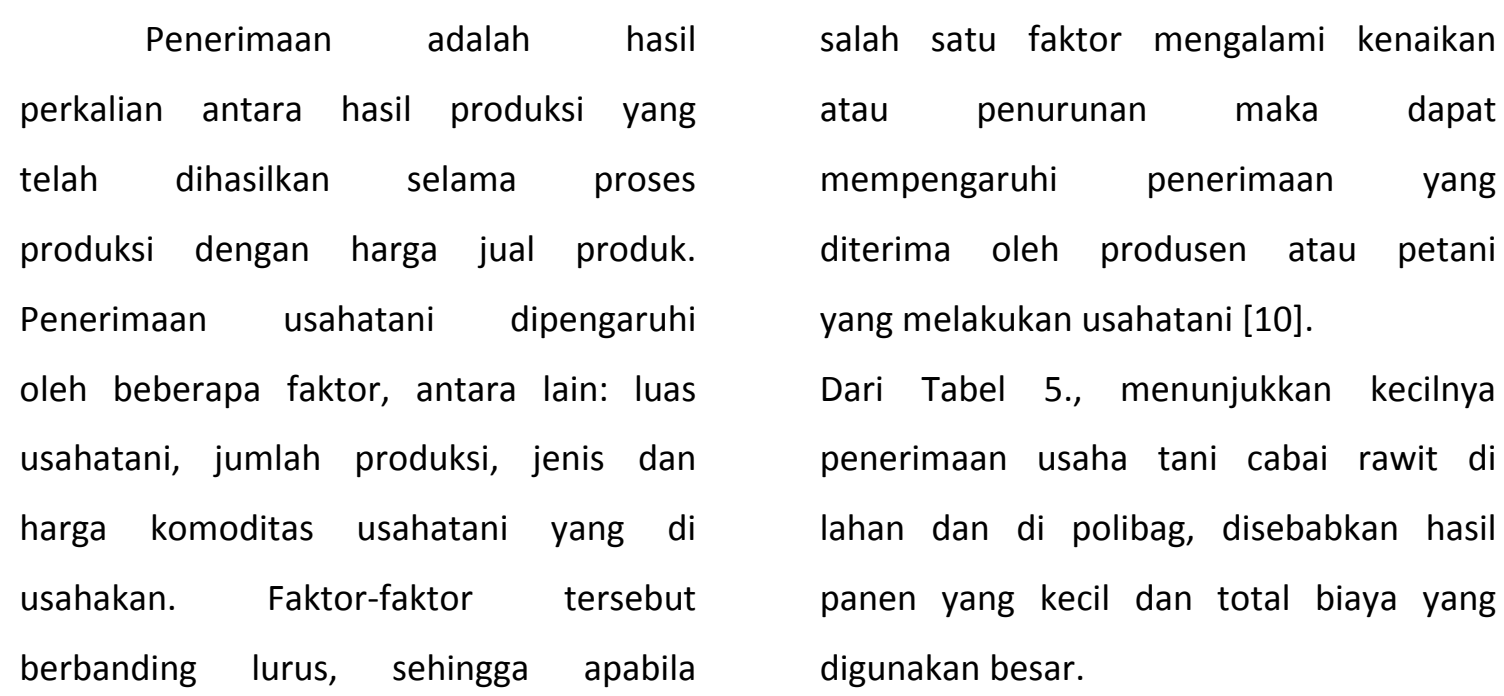


Jurnal IImiah Respati

Keuntungan

Tabel 7. Keuntungan Usaha Tani Cabai Rawit di Lahan dan di Polibag

\begin{tabular}{lcll}
\hline Perlakuan & $\begin{array}{c}\text { Jumlah Penerimaan } \\
(\mathrm{kg})\end{array}$ & $\begin{array}{c}\text { Biaya Total } \\
(\mathrm{Rp})\end{array}$ & $\begin{array}{l}\text { Keuntungan } \\
(\mathrm{Rp})\end{array}$ \\
\hline $\mathrm{T}$ (lahan) & 94.250 & 636.250 & -542.000 \\
$\mathrm{P}$ (polibag) & 57.850 & 476.250 & -418.400 \\
\hline
\end{tabular}

Usaha tani cabai rawit di lahan dan di polibag, belum memberikan keuntungan. Keuntungan dari usaha tani, diperoleh apabila jumlah penerimaan lebih besar dari biaya total [11].

Tanaman cabai rawit yang ditanam di lahan dan di polibag terserang penyakit busuk buah Phytophthora. Phytophthora pada tanaman cabai sebenarnya memiliki posisi yang setara dengan penyakit layu Fusarium, layu bakteri, ataupun antraknosa. Hanya saja, lantaran sering luput dari perhatian, akhirnya keberadaannya sering tidak terkontrol, hingga menimbulkan dampak yang fatal. Phytophthora capsici telah dikenal sebagai salah satu jamur patogen yang mampu menimbulkan kerusakan parah pada hampir semua bagian tanaman cabai [12].
Gejala penyakit ini pada cabai mula mula terjadi bercak kecil kebasahan, berwarna hijau suram, yang meluas dengan cepat sehingga meliputi seluruh buah. Pada buah yang terserang cukup lama akan busuk keseluruhan yang mengakibatkan buah berguguran. Hal ini terjadi karena penanaman cabai rawit terlalu rapat, dan dalam kondisi musim hujan, sehingga pada saat panen tidak optimal.

\section{RC-Ratio}

RC-Ratio merupakan analisis imbangan biaya dengan penerimaan, digunakan untuk mengetahui tingkat efisiensi ekonomi dan menunjukkan daya saing dari produk yang dihasilkan pada usaha tani. Analisis ini digunakan untuk melihat keuntungan dan kelayakan dari usaha tani.

Tabel 8. RC-Ratio Usaha Tani Cabai Rawit di Lahan dan di Polibag Perlakuan Penerimaan (TR) Biaya Total (TC) RC $=T R / T C$ $(\mathrm{Rp}) \quad(\mathrm{Rp})$

\begin{tabular}{llll}
\hline $\mathrm{T}$ (lahan) & 94.259 & 502.500 & 0.188 \\
$\mathrm{P}$ (polibag) & 57.839 & 468.500 & 0.123 \\
& & & \\
\hline
\end{tabular}


Dari Tabel 8., di atas, nilai RC- ratio dari usaha tani cabai rawit di lahan dan di polibag $<1$, dikatakan usaha ini tidak layak untuk dijalankan. Nilai RC-ratio yang menunjukkan efisien dan usaha dapat dijalankan karena akan memberikan keuntungan adalah lebih dari 1 [13]. Nilai RC-Ratio ini, rendah, berhubungan dengan penerimaan dari usaha tani cabai rawit yang rendah, disebabkan panen tidak optimal.

\section{SIMPULAN}

Hasil pengamatan terhadap

pertumbuhan tanaman Cabai Rawit di lahan pekarangan dan di polibag sebagai berikut :

1. Tinggi tanaman, jumlah daun, dan berat segar buah tanaman cabai rawit yang di tanam di lahan lebih besar dari pada di polibag.

2. Produktivitas cabai rawit cabai rawit yang di tanam di lahan lebih besar dari pada di polibag.

3. Usaha tani cabai rawit yang di tanam di lahan dan di polibag tidak efisien atau tidak layak.

\section{DAFTAR PUSTAKA}

[1] Soelaiman, V., Ernawati, A. 2013. Pertumbuhan dan Perkembangan Cabai Keriting (Capsicum annuum I.) Secara In
Vitro pada Beberapa Konsentrasi $B A P$ dan IAA. Buletin Aghorti Vol. 1 (1) : 62-66

[2] Direktur Jenderal Bina Produksi Hortikultura, 2015. Statistik Hortikultura Tahun 2014. Dirjen Hortikultura, Departemen Pertanian Jakarta.

[3] Devi, RN. 2010. Budidaya Tanaman Cabai Merah (capsicum annum L.) Di uptd Pembibitan Tanaman Hortikulutura. Fakultas Pertanian Universitas Sebelas Maret Surakarta

[4] Sudarmi, Nugraheni R, Catur Rini SN, Yos Wahyu H, dan Agung Setyarini, 2013. Kajian Dosis Pupuk NPK terhadap Hasil dan Analisis Usaha Tani Cabai Rawit Rama (Capsicum Frutesence). Skripsi Fakultas Pertanian Universitas Bangun Nusantara Sukoharjo.

[5] Gudi Baru H, Dian Tariningsih, I Made Tamba (2015). Analisa Pendapatan Usaha Tani di Desa Antapan. (Studi Kasus di Desa Antapan Kecamatan Baturiti Kabupaten Tabanan. Skripsi. Fakultas Pertanian Universitas Mahasaraswati Denpasar.

[6] Samekto, R. 2006. Pupuk Kompos. PT Intan Sejati. Klaten. 
[7] Purwadi E, 2011. Batas Kritis Suatu Unsur Hara dan Pengukuran Kandungan Klorofil.(URL : /masbied.com/2011/05/19/batas

-kritis-suatu-unsur-hara-danpengukuran-kandungan-klorofil)

[8] Simamora, S., Salundik, Sriwahyuni dan Surajin. 2005. Membuat Biogas Pengganti Bahan Bakar Minyak dan Gas Dari Kotoran Ternak. Agromedia Pustaka, Bogor.

[9] Surtinah. 2007. Kajian Tentang Hubungan Pertumbuhan Vegetatif Dengan Produksi Tanaman Tomat (Lycopersicum esculentum, Mill).Jurnal Ilmiah Pertanian Vol. 4 No. 1: 1-9
[10] Ambarsari, W., V. D. Y. B Ismadi dan A. Setiadi. 2014. Analisis Pendapatan dan Profitabilitas Usahatani Padi (Oryza sativa) di Kabupaten Indramayu. Jurnal Agri Wiralodra. 6 (2) : 19-27

[11] Soekartawi. 2010. Analisis Usahatani. UI Press, Jakarta.

[12] Semangun, H. 2007. PenyakitPenyakit Tanaman Hortikultura di Indonesia. Gajah Mada University Press. Yogyakarta.

[13] Harmono dan Handoko, A, 2005. Budidaya dan Peluang Bisnis. Agromedia Pustaka Jakarta 